ELORE (ISSN 1456-3010), vol. $16-2 / 2009$.

Julkaisija: Suomen Kansantietouden Tutkijain Seura ry.

[http://www.elore.fi/arkisto/2_09/kirjallisuus_koski_2_09.pdf]

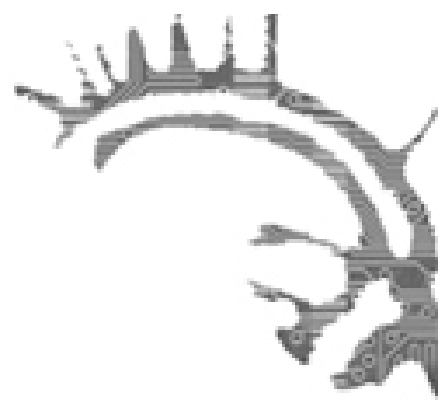

\title{
KiRJA-ARVIO:
}

\section{TAULUKOT KERTOVAT}

Piispanen, Sirkku 2009: Kansanomainen moraali. Tutkimus savolaisista ja pohjalaisista uskomustarinoista. Mikkeli: Sirkeku Piispanen. [online]

<http:// urn.fi/URN:ISBN:978-952-10-5376-4>. 380 sivua.

\section{Kaarina Koski}

Sirkku Piispasen väitöskirja Kansanomainen moraali on erilaista folkloristiikkaa. Teokseen on syytä tarttua erilaisin odotuksin kuin muihin alan väitöskirjoihin viime vuosilta. Analyysi on kvantitatiivinen. Aineistoksi valitut 3120 uskomustarinaa on taulukoitu tiivistämällä niiden tärkeimmät piirteet 32-kohtaiseen muuttujaluetteloon, jolloin tuloksiksi on saatu 106 taulukollista täsmällisiä prosenttilukuja. Laskennallinen analyysi sivuuttaa väistämättä monia laadullisen tutkimuksen kriteereitä, joita nykyaikaisessa folkloristiikassa pidetään tärkeinä. Mutta vastaavasti se antaa kiistatta myös tuloksia, joihin laadullinen tutkimus ei koskaan yllä - eikä tosin edes tähtää.

\section{ELINOLOT MUOKKAAVAT MENTALITEETTIA JA MORAALIA}

Tutkimus vertailee toisiinsa savolaisia ja pohjalaisia uskomustarinoita. Piispanen taustoittaa analyysinsa laajasti talous- ja sosiaalihistoriallisilla tiedoilla sekä rikostilastoilla. Savosta piirtyy kuva sotien ja sotaväenottojen rasittamana, köyhempänä ja harvempaan asuttuna alueena, jossa painottuu väestön yksilöllinen ja maltillinen asenne. Sitä verrataan vauraampaan, yhteistoimintaa ja yhteisöllisyyttä korostavaan, omanarvontuntoisempaan Pohjanmaahan, jossa säätyrajat ja moraalinormit olivat tiukemmat. Erot talous- ja elinolosuhteissa heijastavat eroa väestön mentaliteetissa, mikä edelleen näkyy myös tarinastossa. Kertomusten teemojen esiintymät noudattavatkin paikoin yllättävän suoraan rikostilastoja. Esimerkiksi Etelä-Pohjanmaalla tiivis sosiaalinen kontrolli 


\section{KaARINA KOSKI}

vähensi naimattomien naisten raskauksia, joiden seurausta lapsensurmat useimmiten olivat. Siksi naisten tekemät rikkomukset olivat Etelä-Pohjanmaalla harvemmin surmia kuin muilla tutkituilla alueilla. Pohjois-Savon erityispiirteenä taas oli herätysliikkeiden vaikutus, joka lievensi rikostilastoja ja näkyi tarinoissa siten, että normeille esitettiin muita alueita useammin kristillinen arvoperuste.

Piispasen käyttämä historiatieto toimii erittäin hyvin kontekstina arkistoidulle tarinaperinteelle. Aihelmien ja tulkintojen tiivis kiinnittyminen elinoloihin osoittaa jälleen kerran, ettei perinne ollut agraarikulttuurissakaan vain perittyä ja toisteltua vaan eli ja varioi ajan ja ympäristön luomien tarpeiden mukaan.

\section{TULKINNAN JA RAJAUKSEN ONGELMIA}

Piispasen työssä esikuvana on epäilemättä ollut Matti Sarmela, jonka artikkeli "Talonhaltiat sosiaalisessa kilpailussa. Suomalaisen haltiaperinteen alueellisista eroista" (1974) esittää suppeammasta aineistosta taulukoiden ja karttojen avulla tärkeimmät havainnot Savon ja Pohjanmaan välisistä eroista. Tarina-aineiston taulukointi lähtee olettamuksesta, että tarinoiden sisältö voidaan tulkita riittävän yksiselitteisesti, jotta sen voi luokitella johonkin tutkimuksessa käytetyistä analyysiyksiköistä. Tällaista olettamusta alettiin folkloristiikassa pitää ongelmallisena viimeistään 1980-luvulla yleistyneen merkitysten tutkimuksen (esim. Honko 1984) myötä, kun tekstit alettiin nähdä moniäänisinä ja monitulkintaisina. Määrällisessä analyysissa tutkija joutuu valitsemaan kullekin tarinalle yhden, sen ainoan oikean tulkinnan, mikä on vaikeaa kun aineistona on pelkkä teksti ilman kontekstitietoja tai äänenpainoja. Hyvällä tahdolla voidaan ajatella yleisimpien tulkintojen nousevan märällisesti esiin kaikesta huolimatta, kun aineisto on näinkin laaja. Silti tulos on luotettava vain, jos tutkijan teksteistä tekemät tulkinnat ovat uskottavia.

Piispasen tekemässä analyysissa normirikkomusten kolme pääluokkaa ovat rikkomukset lakia sekä kristillistä ja sosiaalista tapakäyttäytymistä vastaan. Osa rikoksista voi kuulua useampaan pääluokkaan. Taulukoissaan Piispanen on jakanut normirikkomusten yliluonnolliset seuraukset seitsemäksi ongelmatyypiksi lukuisine alatyyppeineen ja luokitellut vastaavalla tavalla myös esimerkiksi yliluonnollisen kokijat sekä ongelmanratkaisutyypit ratkaisijoineen. Luokittelussa käytettyjen tulkintojen perusteet jäävät kuitenkin niin niukoiksi, ettei lukija saa kunnon eväitä niiden arviointiin. Päätelmiä voi tehdä vain esimerkkikertomusten pohjalta.

Esimerkeissä tulkinnat tuntuvat välillä perusteettomilta. Miksi esimerkiksi onnettomuus, jonka aiheuttajaa ei mainita suoraan, on niin usein tulkittu Jumalan rangaistukseksi? Lukijaa ei tyydytä selitys, että kansanuskossa ja aitiologisissa tarinoissa Jumala on mielletty pirua vahvemmaksi (s. 92). Ja miksi myös vainajien kunnioitusta käsitellään erityisemmin problematisoimatta kristillisenä normina? Kirkkohan itse asiassa vastusti vainajien märäävää asemaa kansanuskossa. Tämä luokitusongelma kytkeytyy koko tutkimusaineiston ja analyysin rajaamiseen. Tässä tutkimuksessa ei ole sellaista analyyttista luokkaa, johon etnistä kansanuskoa edustavat, profaanin ja tuonpuoleiseksi määrittyvän pyhän väliset rajaloukkaukset voisivat kuulua. Etnisen 
uskon arvoille ei ole itse asiassa lainkaan sijaa, vaan kaikkia uskonnollisia normeja on tarkasteltu kristinuskon kehyksestä. Tekijän mukaan aineistoksi valitut tarinatyypit "sisältävät monipuolisesti kertomuksia erilaisista rikkomuksista" (s. 21). Tosiasiassa valittuna on vain sellaisia rikkomuksia, joiden tuomittavuus voidaan perustella meille kaikille tutulta länsimais-kristilliseltä arvopohjalta. Tällainen käsittelytapa yksinkertaistaa kuvaa kansanomaisesta moraalista. Toki se on kristinuskon asemaa painottaessaan oikeansuuntainen ja tekee tuloksista suurelle yleisölle ja muiden alojen tutkijoille ymmärrettävämpiä. Mutta rajattiinko kiinnostavin osa nyt pois?

\section{TALOLLISTEN PERINNETTÄ}

Tutkimuksessa on otettu huomioon sekä kertojien että tarinan henkilöiden sosiaaliryhmä ja sukupuoli. Tuloksissa näkyvät siis eri sosiaaliryhmien ja sukupuolen väliset suhteet toisiinsa kertojina ja kerronnan kohteina. Vaikka naisia koskee tutkimuksen mukaan tiukempi normisto kuin miehiä, naisten käytöstä ovat valvoneet - toisin sanoen naisten tekemistä rikkomuksista ovat kertoneet - ennen kaikkea naiset itse. Sosiaaliryhmien välistä vastakkainasettelua ei aineistosta löydy: näissä uskomustarinoissa talolliset itse moralisoivat toisia talollisia (s. 84-86; taulukko 2). Tarinoista piirtyy kuva vertaisryhmän sisäisenä kontrollina. Tulos on kiinnostava, mutta väittäisin sen perustuvan osittain jo aineiston keruussa syntyneeseen vinoumaan. Piispasen aineistossa kolme viidestä maalaisväestöön kuuluvasta kertojasta, joiden ammatti tai asema on tiedossa, on ollut maanomistajia. Tämä ei vastaa todellisia oloja: Matti Sarmelan $(1974,356)$ mukaan vain kymmenisen prosenttia maaseudun väestöstä todella omisti maata. Vaikka Kansanrunousarkiston aineistojen keruuseen osallistuivat kaikki kansanosat, tallentajina dominoivat määrällisesti talolliset sekä oppineet, kuten kansakoulunopettajat, ylioppilaat ja papit, joka kaikki jututtivat luontevimmin hyväosaisia (vrt. Haavio 1931, 78-79; Peltonen 2004, 211). Talonpoikien yliedustus aineistossa ei merkitse, että uskomustarinat olisivat vain heidän perinnettään, vaan että keruu kohdistui etupäässä heihin. Talolliset edustavat kansankulttuurin normatiivista hegemoniaa ja uskomustarinoiden konventionaalisia tulkintatapoja. Muut kansanosat ovat esittäneet samojen juonien ja motiivien avulla toisenlaisia tulkintoja ja arvoja ja myös kyseenalaistaneet vallitsevaa järjestystä (esim. Sarmela 1974; Raudvere 1993), mutta heidän äänensä ei kuulu tässä.

Oikeastaan tämän voi lukea oikeutukseksi kvantitatiiviselle otteelle: koska suuri osa aineiston mahdollisesta moniäänisyydestä on karsiutunut jo keruuvaiheessa, tutkija voi yhtä hyvin keskittyä vain kansankulttuurin hegemoniseen ytimeen. Tässä on todellakin kyse yleisestä ja kollektiivisesta. Kun ymmärretään ja hyväksytään se aineiston ja luokitustavan tuoma rajaus, että tutkimuskohteena ovat tosiasiassa vain talollisväestön konventionaaliset tulkinnat yleisistä länsimais-kristilliseen kulttuuriin pohjautuvista moraalikäsityksistä, Piispasen taulukot ovat kiehtova ja avartava tietolähde. Ne voisivat, rajauksen huomioiden, tarjota aineksia muihinkin tutkimuksiin kuin tähän väitöskirjaan. 


\section{KAARINA KOSKI}

\section{TÄSMÄLLISTÄ TIETOA}

Vaikka tarinoiden työstäminen analyysiyksiköiksi ja taulukointi on ollut varsinainen suurtyö, teoksen tärkeää antia on myös tarinoiden tiivis sitominen historialliseen tietoon ja tulosten tulkinta sen pohjalta. Tulkinta rajoittuu kuitenkin aineiston aihepiirien välittömiin taustatietoihin eikä tekijä heittäydy keskusteluun muiden tutkijoiden kanssa; esimerkiksi tulosten yhtäpitävyydet ja erot Sarmelan tutkimukseen jäävät käsittelemättä. Tulokset sidotaan yhteen enemmän historian kuin folkloristiikan tutkimuksen kanssa.

Piispanen on tehnyt laajasta aineistosta myös kerrontaa koskevia huomioita ja soveltaa etenkin Anna-Leena Siikalan (1984) esittämiä malleja, joskaan ne eivät liity kiinteästi hänen omaan analyysiinsa. Erityisen kiinnostavia ovat kuitenkin laajasta aineistosta tehdyt havainnot kertojien suhtautumisesta kerrottavaansa, joiden myötä voi konkreettisesti seurata uskomusperinteen uskottavuuden rapautumista: Ennen 1930-luvulla tehtyjä suurkeruita kertojien esittämät kommentit ovat olleet etupäässä todenperäisyyttä vahvistavia. 1930-luvulla alkaa itää paitsi epäilyksen siemen, myös kerrotun sijoittaminen menneisyyteen ja vanhojen puheiksi. 1950- ja 1960-luvuilla epäilevät kommentit lisääntyvät osin aikojen muutoksen, osin nauhoitustekniikan salliman runsaamman kommentoinnin myötä. Piispasen aineisto ulottuu 1980-luvulle saakka. (s. 123-126.)

Vaikka kvantitatiivinen analyysi joutuu vetämään tulkinnallisia mutkia suoriksi, se antaa vastaavasti suuresta aineistopohjasta abstrahoituja täsmällisiä tuloksia. Selkeiden prosenttilukujen tukemana on nyt vaivatonta todeta esimerkiksi, että keskeisimpänä naisten synneistä on pidetty huonoa ja syntistä elämää - paitsi Etelä-Pohjanmaalla, missä varallisuuden status yhteisöelämässä on nostanut trullitarinoiden myötä oman edun tavoittelun yleisemmin käsitellyksi synniksi. Teos osoittaa tärkeällä tavalla maakuntien välisen erilaisuuden: Suomi ei ole ollut mentaliteetiltaan homogeeninen maa. Eroista huolimatta monet piirteet ovat olleet koko aineistossa melko yhtäpitäviä. Tähän tutkimukseen tutustumista voi suositella niille, jotka tarkastelevat 1800-luvun kansanomaista mentaliteettia - etenkin Savon ja Pohjanmaan osalta. Uskoisin näiden analyysien hyödyllisyyteen etenkin historiantutkimuksessa.

\section{KirjallisuUs}

HAAVIO, MARTTI 1931: Kansanrunouden keruu ja tutkimus. - Suomi V:12.

HONKO, LAURI 1984: Folkloristic studies on meaning. An Introduction. - Arv. Scandinavian Yearbook of Folklore 40.

PELTONEN, ULLA-MAIJA 2004: Kalevalan riemuvuoden kilpakeruu ja hyvän kerääjän käsite. - Kurki, Tuulikki (toim.), Kansanrunousarkisto, lukijat ja tulkinnat. Helsinki: SKS.

RAUDVERE, CATHARINA 1993: Föreställningar om maran $i$ nordisk folktro. Lund: Religionshistoriska avdelningen, Lunds universitet. 
SARMELA, MATTI 1974: Talonhaltiat sosiaalisessa kilpailussa. Suomalaisen haltiaperinteen alueellisista eroista. - Sampo ei sanoja puntu. Kalevalaseuran vuosikirja 54. Porvoo: WSOY.

SIIKALA, ANNA-LEENA 1984: Tarina ja tulkinta. Tutkimus kansankertojista. Helsinki: SKS.

Filosofian maisteri Kaarina Koski valmistelee kansanuskoa ja kerrontaa koskevaa väitöskirjaansa Helsingin yliopistossa folkloristiikan oppiaineessa. 